DR. ELIANA WASSERMANN (Orcid ID : 0000-0002-3146-0478)

Article type : Original Article

Running head: WASSERMANN ET AL.

\title{
Virulence and pCM1 plasmid carriage are related to BOX-PCR fingerprint type in strains of Clavibacter michiganensis subsp. michiganensis that cause bacterial wilt and canker of tomato in Argentina
}

E. Wassermann ${ }^{1}$, M. S. Montecchia ${ }^{1,2}$, V. S. Garaventa ${ }^{3}$, O. S. Correa ${ }^{1}$ and A. M. Romero ${ }^{3}$

1 Universidad de Buenos Aires, Facultad de Agronomía. Departamento de Biología Aplicada y Alimentos. Cátedra de Microbiología Agrícola, Buenos Aires, Argentina

${ }^{2}$ CONICET - Universidad de Buenos Aires, Instituto de Investigaciones en Biociencias Agrícolas y Ambientales (INBA), Buenos Aires, Argentina

3Universidad de Buenos Aires, Facultad de Agronomía. Departamento de Producción Vegetal, Cátedra de Fitopatología, Buenos Aires, Argentina

Corresponding author

M. S. Montecchia, email: mmontecc@agro.uba.ar

Keywords

This article has been accepted for publication and undergone full peer review but has not been through the copyediting, typesetting, pagination and proofreading process, which may lead to differences between this version and the Version of Record. Please cite this article as doi: 10.1111/PPA.13163

This article is protected by copyright. All rights reserved 
cellulolytic activity, Clavibacter michiganensis subsp. michiganensis, pathogenicity genes, population diversity, Solanum lycopersicum

Clavibacter michiganensis subsp. michiganensis $(\mathrm{Cmm})$ causes bacterial wilt and canker in tomato, producing important economic losses worldwide. Its virulence has been related to several putative virulence factors present on a chromosomal pathogenicity island and on plasmids pCM1 and pCM2, in strain NCPPB382. We genotypically characterized a collection of Cmm isolates from the main greenhouse tomato-producing areas of Argentina by BOX-PCR fingerprinting and screened for the presence of genes and plasmids involved in pathogenicity by PCR. In addition, we evaluated in vitro cellulolytic activity and virulence in planta of selected strains. BOX-PCR fingerprinting clustered strains into four groups. Group II was the dominant and included the most virulent strains, while Group III was the smallest and had the least virulent strains. All local strains exhibited similar cellulolytic activity. Most of the examined strains carry two plasmids of similar size to those of NCPPB382, although there were strains with one or three plasmids. By PCR amplification of repA gene, $\mathrm{pCM} 1$ was detected only in strains belonging to Group III, which includes local strains closely related to reference strain NCPPB382. All analysed pathogenicity genes were widespread among strains, and so in strains belonging to Groups I and II, celA found on pCM1 in NCPPB382 could be in the chromosome or in plasmids other than pCM1. This study contributes to a better understanding of the diversity of $\mathrm{Cmm}$ genetic profiles and virulence of strains present in Argentina. Such information could be useful for the selection of strains for screening of host resistance and development of resistant tomato varieties.

\section{Introduction}

Tomato (Solanum lycopersicum) is one of the most important vegetables produced in the world (FAO, 2016). In the horticultural belt that surrounds the cities of Buenos Aires and La Plata, Argentina, 34\% of the greenhouse area is dedicated to this crop (Corvo Dolcet, 2005). This region together with the

This article is protected by copyright. All rights reserved 
Argentinean provinces of Mendoza, Tucumán, and Corrientes, represent the main tomato-producing areas of the country (Argerich and Troilo, 2011).

Clavibacter michiganensis subsp. michiganensis $(\mathrm{Cmm})$ is considered an important bacterial pathogen and a serious threat to the tomato industry worldwide (Sen et al., 2015), and can cause important economic losses (EPPO, 2013; 2016). Yield reductions from 50\% to $80 \%$ have been reported in Europe, Asia, and America (Hausbeck et al., 2000; Kleitman et al., 2008; Tancos et al., 2013).

Pathogen virulence contributes to the extent of yield losses, and although some genetic factors have been proposed to account for virulence in $\mathrm{Cmm}$, there is still no consensus on this matter (Meletzus and Eichenlaub, 1991; Dreier et al., 1997; Jahr et al., 2000; Kleitman et al., 2008; Tancos et al., 2015). In strain NCPPB382, virulence has been related to a chromosomal pathogenicity island (PI) and two plasmids, pCM1 and pCM2 (Gartemann et al., 2008). The PI contains genes coding for serine proteases (e.g., $\operatorname{chp} C, \operatorname{chp} G$, and $p p a A$ ), important for host plant colonization, and a tomatinase (tomA), which putatively deactivates the plant immune system (Eichenlaub and Gartemann, 2011). Plasmids pCM1 and pCM2 carry genes coding for the endo- $\beta$-1,4-glucanase CelA and the serine protease Pat-1, respectively, which are critical factors for bacterial pathogenicity (Dreier et al., 1997; Hwang et al., 2019). Strains lacking any of these two genes are less virulent or nonpathogenic (Meletzus et al., 1993; Kleitman et al., 2008; Milijašević-Marčić et al., 2012; Tancos et al., 2015). Recently, it was demonstrated that a pCM1-like plasmid and CelA cellulase are fundamental for pathogenicity (Thapa et al., 2017), as bacteria cured of this plasmid do not cause any symptoms. Cellulases are the most abundant carbohydrate-active enzymes secreted by Cmm (Thapa et al., 2017). They are responsible for metabolizing the wall of plant cells, conferring bacteria the capacity for xylem invasion.

In a previous study that analysed the diversity of $12 \mathrm{Cmm}$ isolates from Buenos Aires greenhouses through rep-PCR genomic fingerprinting, three different BOX-PCR fingerprint types were detected, with one of them being dominant (Wassermann et al., 2017). The study did not find any relationship between BOX-PCR groups and the year of sampling or location of isolation (Wassermann et al., 2017).

This article is protected by copyright. All rights reserved 
A comprehensive analysis of the genetic diversity of Cmm strains in Argentina is lacking. The only information in this respect comes from our previous study, which included a limited number of strains exclusively from the Buenos Aires area. Also, the corroboration of an association between bacterial genetic profiles and tomato virulence would be a useful tool for the screening of host resistance and development of resistant varieties (Quesada-Ocampo et al., 2012). For these reasons, our objectives were: (a) to identify local strains causing bacterial canker and wilt from the most relevant tomato producing areas in Argentina; (b) to evaluate the presence of pCM1 and pCM2 plasmids and pathogenicity genes in the bacterial strains and their cellulase activity; and (c) to determine if there is a relationship between those characteristics and the virulence of the strains.

\section{Materials and methods}

\subsection{Bacterial strains}

We analysed 52 local Cmm strains isolated from tomato plants showing symptoms of bacterial wilt and canker growing in commercial greenhouses of the main production areas of Argentina (provinces of Buenos Aires, Corrientes, Tucumán, and Mendoza) between 2000 and 2013 (Figure 1, Table 1). In addition, we included two strains isolated from imported commercial tomato seeds and Cmm NCPPB382, obtained from the National Collection of Plant Pathogenic Bacteria (UK), which was used as a reference strain.

Bacteria were isolated on YDC medium as previously described (Wassermann et al., 2017) and preserved in $20 \%$ glycerol at $-80{ }^{\circ} \mathrm{C}$ for long-term storage. The taxonomic identification of the strains was performed by PCR amplification of the intergenic region between the $16 \mathrm{~S}$ and $23 \mathrm{~S}$ rRNA genes using the subspecies-specific PSA-4/PSA-R pair of primers for Cmm (Pastrik and Rainey, 1999; EPPO, 2013).

\subsection{Pathogenicity and hypersensitive reaction tests}

All isolates were characterized by their pathogenicity on tomato plants and by the hypersensitive reaction (HR) they induced on Mirabilis jalapa, as previously described (Wassermann et al., 2017). 


\subsection{Genetic diversity characterization}

Total bacterial DNA was purified using Wizard Genomic DNA Purification Kit (Promega) according to the manufacturer's protocol and adjusted to $50 \mathrm{ng} / \mathrm{ml}$. Prior to this work, we characterized a group of 12 strains with BOX-, ERIC-, and REP-PCR genomic fingerprinting and all cluster analyses showed similar grouping of strains (Wassermann et al., 2017). Therefore in this work we used only BOX-PCR with BOXA1R primer, as previously described (Wassermann et al., 2017). Moreover, BOX-PCR genomic fingerprinting is considered a standard molecular identification test for Cmm (EPPO, 2013). The fingerprints were analysed with the GelCompar II v. 6.6 software (Applied Maths NV). Band identity and intensity data were used to calculate a Pearson's correlation coefficient-based similarity matrix, and the derived relationships between strains were represented with a dendrogram built using the unweighted pair group with arithmetic mean (UPGMA) clustering method.

\subsection{Plasmid profiles}

Plasmid extraction from selected Cmm strains (NCPPB382 and those from virulence tests) was performed according to Zaluga et al. (2014). The extracted DNA was evaluated by loading $5 \mu 1$ on a $0.8 \%$ agarose gel in $1 \times \mathrm{TBE}$ buffer. Gels were run at $50 \mathrm{~V}$ for $20 \mathrm{hr}$ at $4{ }^{\circ} \mathrm{C}$, stained with SYBR Green I nucleic acid stain (Sigma-Aldrich), and photographed under UV light.

\subsection{PCR-based detection of pathogenicity genes and plasmids pCM1 and pCM2}

The presence of pathogenicity genes described on the chromosomal PI and plasmids of NCPPB382 was determined in the local strains. Total DNA was amplified using specific primers for tomA, ppaA, $\operatorname{chpC}, \operatorname{chp} G, \operatorname{celA}$, and pat-1 genes based on the sequence of NCPPB382 (Dreier et al., 1994;

Kleitman et al., 2008; Yim et al., 2012). The presence of pCM1 and pCM2 plasmids was evaluated by PCR amplification of repA of both plasmids using primers based on the sequence of NCPPB382. The primers, annealing temperatures, and expected amplicon sizes are described in Table S1. Amplifications were performed with GoTaq DNA Polymerase (Promega) as described by the manufacturer, with $1 \mu \mathrm{M}$ of each primer and $40 \mathrm{ng}$ template DNA. Amplification conditions were: 94 ${ }^{\circ} \mathrm{C}$ for $10 \mathrm{~min}$; 35 cycles of $94{ }^{\circ} \mathrm{C}$ for $90 \mathrm{~s}, 2 \mathrm{~min}$ at annealing temperature (Table $\mathrm{S} 1$ ), and $72{ }^{\circ} \mathrm{C}$ for 2 min; and a final extension at $72{ }^{\circ} \mathrm{C}$ for $10 \mathrm{~min}$. Reaction products were checked by electrophoresis in

This article is protected by copyright. All rights reserved 
$1.5 \%$ agarose gels in TBE buffer at $150 \mathrm{~V}$ for $90 \mathrm{~min}$ and staining with SYBR Safe DNA gel stain (Invitrogen).

Reference strain NCPPB382 was used as control in all PCRs.

\subsection{Endocellulase activity}

Nine strains selected as representatives of the different BOX-PCR groups (Cm11, Cm66, and Cm99 from Group I; Cm12, Cm27, and Cm34 from Group II; and Cm7, Cm16, and Cm121 from Group III) were tested for endocellulase activity (Meletzus et al., 1993). Strains from $-80{ }^{\circ} \mathrm{C}$ frozen stocks were cultured on YDC agar for $48 \mathrm{hr}$. Afterwards, one colony was touched with a sterile pipette tip and inoculated in a Petri dish containing M9 medium modified for Cmm (Flügel et al., 2012) with 0.5\% of carboxymethylcellulose (Britania) as carbon source instead of glucose. Bacteria were cultured for 5 days at $25^{\circ} \mathrm{C}$, and then the dishes were stained with $0.1 \%$ Congo Red for $20 \mathrm{~min}$ and rinsed five times with $1 \mathrm{M} \mathrm{NaCl}$. The presence of a clear halo around colonies was recorded as evidence of endocellulase activity, and the diameter of the halos was measured to compare the activity between strains. The experiment was repeated twice. Cmm NCPPB382 and Escherichia coli DSM 1116 were included as positive and negative controls, respectively.

\subsection{Virulence tests}

The virulence of 20 strains randomly selected by BOX-PCR groups was evaluated, six from Group I (Cm11, Cm26, Cm47, Cm54, Cm66, and Cm99), eight from Group II (Cm2, Cm9, Cm12, Cm27, Cm34, Cm38, Cm42, and Cm90), and six from Group III (Cm7, Cm16, Cm17, Cm43, Cm120, and Cm121).

Inoculations were performed on tomato plants cultivar ACE 55 (Asgrow Seed Co.) grown in individual $1 \mathrm{~L}$ pots containing compost:perlite (4:1 vol/vol). Plants were watered and fertilized twice a week with a solution containing $\left.0.4 \mathrm{~g} \mathrm{Ca} \mathrm{NO}_{3}\right)_{2}, 0.27 \mathrm{~g} \mathrm{KNO}_{3}, 0.27 \mathrm{~g} \mathrm{KH}_{2} \mathrm{PO}_{4}$, and $0.24 \mathrm{~g} \mathrm{MgSO}$ per litre of tap water.

To prepare bacterial inocula, Cmm strains grown on YDC at $28^{\circ} \mathrm{C}$ for $72 \mathrm{hr}$ were suspended in sterile distilled water, and their concentrations were adjusted with a spectrophotometer (Jenway

This article is protected by copyright. All rights reserved 
$7315)$ to $10^{8} \mathrm{cfu} / \mathrm{ml}\left(\mathrm{OD}_{590}=0.3\right)$. For inoculation, suspensions were diluted to a $10^{7} \mathrm{cfu} / \mathrm{ml}$ final concentration.

Plants (six or seven leaves) were inoculated by placing $20 \mu 1$ of the bacterial suspension at the base of the second true leaf and puncturing the stem through the drop of inoculum with a sterile insulin needle. Inoculated plants were kept in a greenhouse under natural light (c. $14 \mathrm{hr}$ ) and temperature $\left(18-28{ }^{\circ} \mathrm{C}\right)$ conditions.

Virulence was evaluated through three variables: the first day post-inoculation (FDPI) when symptoms were observed, the area under disease progress curve (AUDPC), and the severity of the vascular discoloration of the stems. To calculate the AUDPC, the incidence of wilted leaves per plant (proportion of wilted leaves over the total number of leaves) was evaluated every 3 or 4 days for a total of six observations. AUDPC was calculated as described by the following formula:

$$
\mathrm{AUDPC}=\sum_{i}^{n-1}\left(\frac{y_{i+1}+y_{i}}{2}\right)\left(t_{i+1}-t_{i}\right)
$$

where: $n$ is the total number of evaluations, $y_{\mathrm{i}}$ is the incidence of wilting leaves measured on day $t_{\mathrm{i}}$ $(\%), y_{\mathrm{i}+1}$ is the incidence of wilting leaves measured on day $t_{\mathrm{i}+1}(\%)$, and $\left(t_{\mathrm{i}+1}-t_{\mathrm{i}}\right)$ is the period between two measurements (days).

At the end of the experiment, plants were harvested, and stem severity was measured as the proportion of stem length with vascular discoloration over total stem length.

The experiment was repeated five times; in autumn and spring 2014 and 2016 and in autumn 2017. All experiments included a negative control inoculated with water.

For the statistical analysis, AUDPC and FDPI data were relativized to the highest value in each experiment. Data were analysed with a linear mixed model. Differences were assessed with Tukey's test. The fixed variable was the BOX-PCR group the strain belonged to, and the random variables were the stem severity and the relativized values of AUDPC and FDPI. Statistical analyses were done with R v. 3.0.1 (R Core Team, 2014).

This article is protected by copyright. All rights reserved 


\section{Results}

\subsection{Identification of isolated local bacteria}

All strains caused an HR on M. jalapa $48 \mathrm{hr}$ after infiltration. In the pathogenicity tests, all inoculated tomato plants had one or two leaves wilted 2 weeks after inoculation. Molecular identification of isolates allowed the assignment of all strains to $\mathrm{Cmm}$; all of them amplified the expected size PCR product (270 bp) in the PCR test with the Cmm-specific primer set.

Cluster analyses of genomic fingerprints grouped local strains in four distinctive BOX-PCR clusters defined at $88 \%$ similarity level. Most of the strains, 32, clustered in Group II. Group I included 15 strains, while Group III clustered 8 strains, closely related to the reference strain NCPPB382 (Group IV) (Figure 2). Within each group, all local strains showed highly similar BOXPCR fingerprints. Similarity between strains within each group was approximately $89 \%$ to $95 \%$.

Some of the strains within a group were isolated from the same greenhouse in different years, such as the pairs $\mathrm{Cm} 39 / \mathrm{Cm} 42$ and $\mathrm{Cm} 46 / \mathrm{Cm} 12$. In one occasion we obtained three isolates from a plant, two of them isolated from different sections of the stem ( $\mathrm{Cm} 94$ and $\mathrm{Cm} 98)$ which corresponded to BOX-PCR Group I, while the isolate obtained from a petiole (Cm95) corresponded to Group II.

No relationship was observed between BOX-PCR clustering and the geographical origin of the strains. Group II included strains that had been isolated from the four production areas of Argentina. Strains isolated from the same production area or from seeds clustered in at least two different BOXPCR clusters.

\subsection{Pathogenicity genes in local populations}

All local strains showed positive PCR amplification for the studied pathogenicity genes: tomA, ppaA, chpC, and $\operatorname{chpG}$ located in the chromosomal PI in NCPPB382, and celA and pat-1 located on plasmids pCM1 and pCM2 in NCPBB32, respectively. As expected, reference strain NCPPB382 amplified all analysed pathogenicity genes (Table 1).

This article is protected by copyright. All rights reserved 


\subsection{Presence of plasmids pCM1 and pCM2}

PCR with primers based on repA gene of plasmid pCM1 of NCPPB382 rendered the expected amplification product only with strains that clustered in BOX-PCR Group III (Table 1). In contrast, all strains, except Cm98, amplified the repA gene of plasmid pCM2 of NCPPB382. Reference strain NCPPB382 amplified the repA genes of both plasmids (Table 1). Interestingly, plasmid analysis of strains representing all BOX-PCR groups revealed different profiles of one to three plasmids, with most strains carrying two plasmids with similar sizes to those of NCPPB382 (Figure 3).

\subsection{Virulence and BOX-PCR Group}

Strains from each BOX-PCR group were evaluated for their virulence using three descriptive variables: AUDPC, stem severity, and FDPI (Figure 4). There were differences between groups for all three variables (ANOVA; $p<.015, p<.03$ and $p<.008$, respectively). Strains of BOX-PCR Group II were associated with significantly higher values of AUDPC (Figure 4a) and lower values of FDPI (Figure 4b) than those of Group III (Tukey's test, $p<.05$ ). Stem severity was significantly highest in plants infected with Group II strains, intermediate for Group I and lowest for Group III (Figure 4c).

Endocellulolytic activity of the strains showed no relationship with BOX-PCR groups; all strains gave a positive result, with no statistical differences in the diameter of the degradation halo between strains, and with a diameter similar to Cmm NCPPB382.

\section{Discussion}

We studied the virulence of a collection of $\mathrm{Cmm}$ strains isolated from the four main greenhouse production areas of Argentina over a period of 14 years, in relation to genomic fingerprints, presence of genes and plasmids involved in pathogenicity, and cellulolytic activity of the strains.

All the isolates included in the study were pathogenic on tomato. The strains of $\mathrm{Cmm}$ established in Argentina were moderately diverse and were divided into three BOX-PCR groups. The number of fingerprint types agreed with our previous work, based on the analysis of a smaller

This article is protected by copyright. All rights reserved 
collection of strains from Buenos Aires (Wassermann et al., 2017). In comparison with other studies, we identified a lower number of BOX-PCR groups among local $\mathrm{Cmm}$ strains. In other regions, four groups have been identified (Louws et al., 1998; Kleitman et al., 2008; Kawaguchi et al., 2010; Quesada-Ocampo et al., 2012; Tancos et al., 2015; Ialacci et al., 2016) with one group that was prevalent over the others, and in some cases including NCPPB382 (Tancos et al., 2015; Ialacci et al., 2016).

The presence of a dominant cluster seems to be a common theme in different regions of the world (Nazari et al., 2007; Milijašević-Marčić et al., 2012; Quesada-Ocampo et al., 2012; Tancos et al., 2015; Ialacci et al., 2016). In this study, BOX-PCR Group II was dominant, with 59\% of the local strains. It is possible that strains from this group, which also contains those that were most virulent, are well adapted to the environmental conditions, persisting locally to a higher degree than other strains. Further studies, in contrasting environments, could help to elucidate whether virulent strains are better adapted to local environmental conditions than less virulent strains.

The moderate diversity detected could be explained, at least in part, by the local persistence of the pathogen. Such a finding was also proposed in the Canary Islands, Spain, where a high homogeneity was observed (de León et al., 2009). It is known that Cmm can survive in host debris from one season to the next (Gleason et al., 1993; Vega and Romero, 2016) and, as we observed in both the present and previous studies, some of the strains isolated from the same greenhouse in different years grouped together, suggesting local persistence over time. In addition, it is also possible that the source of origin of the imported seeds is limited, reducing the chances of introducing many different genotypes.

All three Cmm genetic groups were detected is Buenos Aires and Mendoza. This could be related to the fact that in Argentina, there are large specialized companies that produce and distribute seedlings to growers in different provinces. It is interesting to note that two of the strains included in this study were isolated from seeds provided by one of these companies and those strains belong to the two main groups (I and II). If infected seedlings are commercialized over long distances, the same $\mathrm{Cmm}$ fingerprint type would be introduced to different locations. Otherwise, in Corrientes and Tucumán, we identified only two groups, possibly due to the low number of samples included in the 
study. However, we cannot discard differences in the adaptability of strains to different environmental conditions.

Understanding the population structure of the pathogen may help to develop specific disease management strategies. In this study, strains from two different BOX-PCR groups (Cm95, Group II; and Cm94 and Cm98, Group I) were isolated from the same plant; something similar was reported in the USA (Quesada-Ocampo et al., 2012). Different strains on the same plant might have different origins. Furthermore, we have isolated strains from different BOX-PCR groups in the same greenhouses at the same sampling time, suggesting that $\mathrm{Cmm}$ strains in Argentina originate from both seeds and debris, which can coexist in the same greenhouse (Wassermann et al., 2017). Preventive measures, such as crop rotation, tool sanitation and the use of certified seeds and seedlings, could help avoid these infections. However, in Argentina, as in many other parts of the world, tomato growers are highly specialized and produce tomato continuously, with low possibility of rotation with other crops. Also, certification of seeds as free of $\mathrm{Cmm}$ is not mandatory, because it is not a quarantine disease.

PCR detection of plasmid pCM1 only in strains from BOX-PCR Group III was unexpected. Even though pCM1 plasmid was not detected in most local strains, all amplified celA gene. Plasmids pCM1 and pCM2 are considered essential for pathogenicity in NCPPB382 (Meletzus et al., 1993). Despite all sequenced pathogenic strains having pCM1 like-plasmids (Nandi et al., 2018), wild strains of $\mathrm{Cmm}$ are reported to have considerable diversity in the presence and composition of plasmids (Kleitman et al., 2008; Thapa et al., 2017), as we have also confirmed in local Argentinean strains. It is possible that PCR-based detection of pCM1 in Argentinean strains of BOX-PCR Groups I and II failed due to divergence in repA sequences (Nandi et al., 2018). Kleitman et al (2008) also observed that $c e l A$ was present in strains that did not amplify the expected product for repA gene of pCM1 plasmid. Therefore, in strains of BOX-PCR Groups I and II, celA could be located in pCM1-like plasmids or in the chromosome. CelA is considered to have an essential role in virulence. Several studies (Meletzus et al., 1993; Thapa et al., 2017; Hwang et al., 2019) showed that nonpathogenic mutant strains lacking celA restored their pathogenicity when the gene was reincorporated. However, in New York State and Uruguay $6 \%$ and $2.5 \%$ of the strains, respectively, did not amplify celA even

This article is protected by copyright. All rights reserved 
though they were pathogenic (Tancos et al., 2015; Croce et al., 2016). In our case, all local strains were pathogenic and exhibited similar endocellulase activity in vitro. Plasmid pCM2 is assumed to be less conserved in gene content, with strains even lacking pCM2 (Bella et al. 2012; Nandi et al., 2018). However, in our study it was detected in all strains but one; strain $\mathrm{Cm} 98$ rendered the expected amplicon for pat- 1 but not for repA from plasmid pCM2 where it is supposed to be located.

The genes analysed in the chromosomal PI were widespread in Cmm local strains. Still, there were significant differences in virulence between them, which might be explained by differences in other pathogenicity genes, gene expression factors, or sequence mutations on the analysed genes. Temperature at the time of inoculation might also affect the expression of pathogenicity genes and consequently symptom expression (Sharabani et al., 2014) in different ways or magnitudes for each strain.

In summary, we conclude that $\mathrm{Cmm}$ strain diversity in Argentina is moderate, with a prevalence of BOX-PCR Group II, which includes the most virulent strains. Strains had one to three plasmids, although most of them had two plasmids with similar sizes to pCM1 and pCM2 of NCPPB382. Plasmid pCM1 with a conserved repA gene is present only in BOX-PCR Group III strains, which were genetically closely related to NCPPB382. On the other hand, plasmid pCM2 appears to be more conserved, at least in relation to repA sequence. Pathogenicity genes celA and pat1 could be located in the chromosome or in plasmids different to those described for NCPPB382. Although pathogenicity genes were widespread, virulence was variable.

In this study we give further evidence that both imported seeds and infested plant debris coexist as sources of primary inoculum of $\mathrm{Cmm}$ in Argentinian greenhouses. Preventive measures should be taken to avoid the introduction of infected/infested material into the production field that may increase the diversity of $\mathrm{Cmm}$ populations and the risk of incorporating more virulent strains.

\section{Acknowledgements}

We thank Ceferino R. Flores, Verónica G. Obregón, and Jorgelina Rolleri for providing some of the Cmm isolates used in this study. We are very grateful to Alicia Lopez, Damian Vega, and Demian

This article is protected by copyright. All rights reserved 
Wassermann for providing valuable comments on an earlier version of this manuscript. This work was supported by Agencia Nacional de Promoción Científica y Tecnológica (PICT 1776 2011-2014) and Universidad de Buenos Aires, Secretaría de Ciencia y Técnica (UBACyT 20020130100501BA 2014-2017). E. Wassermann holds a postdoctoral fellowship from Consejo Nacional de Investigaciones Científicas y Técnicas (CONICET).

\section{Data availability statement}

The data that support the findings of this study are available from the corresponding author upon reasonable request.

\section{References}

Argerich, C. and Troilo, L. (2011) Manual De Buenas Prácticas Agrícolas En La Cadena De Tomate. CABA, Argentina: FAO.

Bella, P., Ialacci, G., Licciardello, G., La Rosa, R. and Catara, V. (2012) Characterization of atypical Clavibacter michiganensis subsp. michiganensis populations in greenhouse tomatoes in Italy. Journal of Plant Pathology, 94, 635-642.

Corvo Dolcet, S. (2005) Zonas de producción del cultivo del tomate en la Argentina. Secretaría de Agricultura, Ganadería, Pesca y Alimentos, 1-15.

Croce, V., Pianzzola, M.J., Durand, K., González-Arcos, M., Jacques, M.-A. and Siri, M.I. (2016) Multilocus sequence typing reveals high variability among Clavibacter michiganensis subsp. michiganensis strains affecting tomato crops in Uruguay. European Journal of Plant Pathology, $144,1-13$.

Dreier, J., Bermpohl, A. and Eichenlaub, R. (1994) Southern hybridization and PCR for specific detection of phytopathogenic Clavibacter michiganensis subsp. michiganensis. Phytopathology,

This article is protected by copyright. All rights reserved 
$85,462-468$.

Dreier, J., Meletzus, D. and Eichenlaub, R. (1997) Characterization of the plasmid encoded virulence region pat-1 of phytopathogenic Clavibacter michiganensis subsp. michiganensis. Molecular Plant-Microbe Interactions, 10, 195-206.

Eichenlaub, R. and Gartemann, K. (2011) The Clavibacter michiganensis subspecies: molecular investigation of gram-positive bacterial plant pathogens. Annual Review of Phytopathology, 49, 445-64.

EPPO (2013) PM 7/42 (2) Clavibacter michiganensis subsp. michiganensis. EPPO Bulletin, 43, 4667.

EPPO (2016) Database on quarantine pests. Available at:

https://onlinelibrary.wiley.com/doi/full/10.1111/epp.12302 [Accessed 10 February 2020].

FAO (2016) Food and Agriculture Organization of the United Nations. Available at:http://www.fao.org/faostat/en/\#data/QC [Accessed 12 December 2017].

Flügel, M., Becker, A., Gartemann, K.H. and Eichenlaub, R. (2012) Analysis of the interaction of Clavibacter michiganensis subsp. michiganensis with its host plant tomato by genome-wide expression profiling. Journal of Biotechnology, 160, 42-54.

Gartemann, K.H., Abt, B., Bekel, T., Burger, A., Engemann, J., Flügel, M. et al. (2008) The genome sequence of the tomato-pathogenic actinomycete Clavibacter michiganensis subsp. michiganensis NCPPB382 reveals a large island involved in pathogenicity. Journal of Bacteriology, 190, 2138-2149.

Gleason, M.L., Gitaitis, R.D. and Ricker, M.D. (1993) Recent progress in understanding and controlling bacterial canker of tomato in eastern North America. Plant Disease, 77, 1069-1076.

Hausbeck, M.K., Bell, J., Medina-Mora, C., Podolsky, R. and Fulbright, D.W. (2000) Effect of bactericides on population sizes and spread of Clavibacter michiganensis subsp. michiganensis on tomatoes in the greenhouse and on disease development and crop yield in the field.

This article is protected by copyright. All rights reserved 
Phytopathology, 90, 38-44.

Hijmans, R.J., Guarino, L., Cruz, M. and Rojas, E. (2001) Computer tools for spatial analysis of plant genetic resources data: 1. DIVA-GIS. Plant Genetic Resources Newsletter, 127, 15-19.

Hwang, I.S., Oh, E.-J., Lee, H.B. and Oh, C.-S. (2019) Functional characterization of two cellulase genes in the Gram-positive pathogenic bacterium Clavibacter michiganensis for wilting in tomato. Molecular Plant-Microbe Interactions, 32, 491-501.

Ialacci, G.M., Bella, P., Licciardello, G., Strano, C.P., Eichenlaub, R., Gartemann, K.H. et al. (2016) Clonal populations of Clavibacter michiganensis subsp michiganensis are responsible for the outbreaks of bacterial canker in greenhouse tomatoes in Italy. Plant Pathology, 65, 484-495.

Jahr, H., Dreier, J., Meletzus, D., Bahro, R. and Eichenlaub, R. (2000) The endo- $\beta-1,4$-glucanase CelA of Clavibacter michiganensis subsp. michiganensis is a pathogenicity determinant required for induction of bacterial wilt of tomato. Molecular Plant-Microbe Interactions 13, $703-714$.

Kawaguchi, A., Tanina, K. and Inoue, K. (2010) Molecular typing and spread of Clavibacter michiganensis subsp. michiganensis in greenhouses in Japan. Plant Pathology, 59, 76-83.

Kleitman, F., Barash, I., Burger, A., Iraki, N., Falah, Y., Sessa, G. et al. (2008) Characterization of a Clavibacter michiganensis subsp michiganensis population in Israel. European Journal of Plant Pathology, 121, 463-475.

de León, L., Rodríguez, A., Llop, P., López, M.M. and Siverio, F. (2009) Comparative study of genetic diversity of Clavibacter michiganensis subsp. michiganensis isolates from the Canary Islands by RAPD-PCR, BOX-PCR and AFLP. Plant Pathology, 58, 862-871.

Louws, F.J., Bell, J., Medina-Mora, C.M., Smart, C.D., Opgenorth, D., Ishimaru, C.A. et al. (1998) rep-PCR-mediated genomic fingerprinting: a rapid and effective method to identify Clavibacter michiganensis. Phytopathology 88, 862-868.

This article is protected by copyright. All rights reserved 
Meletzus, D. and Eichenlaub, R. (1991) Transformation of the phytopathogenic bacterium Clavibacter michiganensis subsp. michiganensis by electroporation and development of a cloning vector. Journal of Bacteriology, 173, 184-190.

Meletzus, D., Bermphol, A., Dreier, J. and Eichenlaub, R. (1993) Evidence for plasmid-encoded virulence factors in the phytopathogenic bacterium Clavibacter michiganensis subsp. michiganensis NCPPB382. Journal of Bacteriology, 175, 2131-2136.

Milijašević-Marčić, S., Gartemann, K.H., Frohwitter, J., Eichenlaub, R., Todorović et al. (2012) Characterization of Clavibacter michiganensis subsp. michiganensis strains from recent outbreaks of bacterial wilt and canker in Serbia. European Journal of Plant Pathology, 134, $697-711$.

Nandi, M., MacDonald, J., Liu, P., Weselowski, B. and Yuan, Z.-C. (2018) Clavibacter michiganensis subsp. michiganensis: bacterial canker of tomato, molecular interactions and disease management. Molecular Plant Pathology, 19, 2036-2050.

Nazari, F., Niknam, G.R., Ghasemi, A., Taghavi, S.M., Momeni, H. and Torabi, S. (2007) An investigation on strains of Clavibacter michiganensis subsp. michiganensis in north and north west of Iran. Journal of Phytopathology, 155, 563-569.

Pastrik, K.H. and Rainey, F.A. (1999) Identification and differentiation of Clavibacter michiganensis subspecies by polymerase chain reaction-based techniques. Journal of Phytopathology, 147, 687-693.

Quesada-Ocampo, L., Landers, N.A., Lebeis, A.C., Fulbright, D.W. and Hausbeck, M.K. (2012) Genetic structure of Clavibacter michiganensis subsp. michiganensis populations in Michigan commercial tomato fields. Plant Disease, 96, 788-796.

R Core Team (2014) R: A Language and Environment for Statistical Computing. Vienna, Austria.: R Foundation for Statistical Computing. Available at: https://www.r-project.org/ [Accessed 10 February 2020].

This article is protected by copyright. All rights reserved 
Sen, Y., van der Wolf, J., Visser, R.G.F. and van Heusden, S. (2015) Bacterial canker of tomato: current knowledge of detection, management, resistance, and interactions. Plant Disease, 99, 413.

Sharabani, G., Manulis-Sasson, S., Chalupowicz, L., Borenstein, M., Shulhani, R., Lofthouse, M. et al. (2014) Temperature at the early stages of Clavibacter michiganensis subsp. michiganensis infection affects bacterial canker development and virulence gene expression. Plant Pathology, 63, 1119-1129.

Tancos, M.A., Chalupowicz, L., Barash, I., Manulis-Sasson, S. and Smart, C.D. (2013) Tomato fruit and seed colonization by Clavibacter michiganensis subsp. michiganensis through external and internal routes. Applied and Environmental Microbiology,79, 6948-6957.

Tancos, M.A., Lange, H.W. and Smart, C.D. (2015) Characterizing the genetic diversity of the Clavibacter michiganensis subsp. michiganensis population in New York. Phytopathology, 105, 169-179.

Thapa SP, Pattathil S, Hahn M, Jacques M-A, Gilbertson B, Coaker G, 2017. Genomic analysis of Clavibacter michiganensis reveals insight into virulence strategies and genetic diversity of a Gram-positive bacterial pathogen. Molecular Plant-Microbe Interactions 30, 786-802.

Vega, D. and Romero, A.M. (2016) Survival of Clavibacter michiganensis subsp. michiganensis in tomato debris under greenhouse conditions. Plant Pathology, 65, 545-550.

Wassermann, E., Montecchia, M.S., Correa, O.S., Vega, D. and Romero, A.M. (2017) Clavibacter michiganensis subsp. michiganensis strains virulence and genetic diversity. A first study in Argentina. European Journal of Plant Pathology, 149, 35-42.

Yim, K.-O., Lee, H.-I., Kim, J.-H., Lee, S.-D., Cho, J.-H. and Cha, J.-S. (2012) Characterization of phenotypic variants of Clavibacter michiganensis subsp. michiganensis isolated from Capsicum annuum. European Journal of Plant Pathology, 133, 559-575.

Załuga, J., Stragier, P., Baeyen, S., Haegeman, A., Van Vaerenbergh, J., Maes, M. et al. (2014)

This article is protected by copyright. All rights reserved 
Comparative genome analysis of pathogenic and non-pathogenic Clavibacter strains reveals adaptations to their lifestyle. BMC Genomics, 15, 392.

\section{Supporting information legend}

Table S1 List of primer sets and annealing temperatures used for detection of target pathogenic genes and reference genes of the plasmids in PCR assays.

\section{Figure legends}

Figure 1 Provinces of Argentina from where Clavibacter michiganensis subsp. michiganensis strains were isolated. The size of the circles represent the surface dedicated to tomato greenhouse production in each region. Map obtained from diva-gis 7.3 (Hijmans et al., 2001).

Figure 2 UPGMA dendrogram based on the Pearson correlation coefficient obtained from BOXPCR genomic fingerprints analysis of Clavibacter michiganensis subsp. michiganensis strains isolated in Buenos Aires, Corrientes, Mendoza, and Tucumán. The groups indicated by I to IV were defined at the $88 \%$ similarity level (dashed line). Strain denomination shown on the right.

Figure 3 Plasmids profile of selected strains of Clavibacter michiganensis subsp. michiganensis from different BOX-PCR groups. Arrows and sizes refer to the plasmids pCM1 and pCM2 of strain NCPPB382.

Figure 4 Virulence characterization of BOX-PCR groups of local strains of Clavibacter michiganensis subsp. michiganensis. (a) Area under the disease progress curve (AUDPC); (b) first day post-inoculation (FDPI) on which plants showed symptoms; and (c) stem severity (discolored stem length/total stem length). Values were relativized to the highest value of each assay. Statistical analysis was done using ANOVA. BOX-PCR Groups II and III were significantly different for all variables (ANOVA, Tukey's test, $p<.05$ ). Bars are standard error of the mean.

This article is protected by copyright. All rights reserved 
Table 1. Results of BOX-PCR genomic fingerprinting and PCR detection of genes involved in plasmid replication (repA-pCM1 and repA-pCM2) and pathogenicity (celA, pat-1, chpC, chpG, ppaA and tomA) of Clavibacter michiganensis subsp. michiganensis strains used in this study.

\begin{tabular}{|c|c|c|c|c|c|c|c|c|c|c|c|c|}
\hline \multirow[t]{2}{*}{ Strain $^{\mathrm{a}}$} & \multirow[t]{2}{*}{ Origin } & \multirow[t]{2}{*}{ Year } & \multirow[t]{2}{*}{ BOX-PCR group } & \multicolumn{8}{|c|}{ Gene $^{b}$} & \multirow[t]{2}{*}{ Source $^{c}$} \\
\hline & & & & repA-pCM1 & repA-pCM2 & celA & pat-1 & $\operatorname{chpC}$ & $\operatorname{chpG}$ & ppaA & tomA & \\
\hline $\mathrm{Cm} 11$ & Buenos Aires & 2000 & $\mathrm{I}$ & - & + & + & + & + & + & + & + & Wassermann et al., 2017 \\
\hline $\mathrm{Cm} 15$ & Mendoza & 2013 & $\mathrm{I}$ & - & + & + & + & + & + & + & + & This study \\
\hline $\mathrm{Cm} 26$ & Buenos Aires & 2011 & I & - & + & + & + & + & + & + & + & Wassermann et al., 2017 \\
\hline $\mathrm{Cm} 28$ & Buenos Aires & 2011 & $\mathrm{I}$ & - & + & + & + & + & + & + & + & This study \\
\hline $\mathrm{Cm} 33$ & Corrientes & 2011 & $\mathrm{I}$ & - & + & + & + & + & + & + & + & V. Obregón \\
\hline $\mathrm{Cm} 45$ & Buenos Aires & 2010 & I & - & + & + & + & + & + & + & + & This study \\
\hline $\mathrm{Cm} 47$ & Buenos Aires & 2010 & $\mathrm{I}$ & - & + & + & + & + & + & + & + & This study \\
\hline $\mathrm{Cm} 54$ & Buenos Aires & 2002 & $\mathrm{I}$ & - & + & + & + & + & + & + & + & Wassermann et al., 2017 \\
\hline Cm57 & Buenos Aires & 2009 & $\mathrm{I}$ & - & + & + & + & + & + & + & + & This study \\
\hline Cm64 & Buenos Aires & 2011 & I & - & + & + & + & + & + & + & + & Wassermann et al., 2017 \\
\hline Cm66 & Buenos Aires & 2012 & $\mathrm{I}$ & - & + & + & + & + & + & + & + & Wassermann et al., 2017 \\
\hline $\mathrm{Cm} 94^{*}$ & Buenos Aires & 2011 & I & - & + & + & + & + & + & + & + & This study \\
\hline $\mathrm{Cm} 97$ & Seeds & 2011 & $\mathrm{I}$ & - & + & + & + & + & + & + & + & Wassermann et al., 2017 \\
\hline $\mathrm{Cm} 98^{*}$ & Buenos Aires & 2011 & $\mathrm{I}$ & - & - & + & + & + & + & + & + & This study \\
\hline Cm99 & Buenos Aires & 2011 & $\mathrm{I}$ & - & + & + & + & + & + & + & + & Wassermann et al., 2017 \\
\hline $\mathrm{Cm} 2$ & Buenos Aires & 2000 & II & - & + & + & + & + & + & + & + & This study \\
\hline $\mathrm{Cm} 9$ & Buenos Aires & 2000 & II & - & + & + & + & + & + & + & + & This study \\
\hline $\mathrm{Cm} 12$ & Buenos Aires & 2001 & II & - & + & + & + & + & + & + & + & This study \\
\hline $\mathrm{Cm} 13$ & Buenos Aires & 2001 & II & ND & ND & ND & ND & ND & ND & ND & ND & This study \\
\hline $\mathrm{Cm} 18$ & Mendoza & 2013 & II & - & + & + & + & + & + & + & + & This study \\
\hline $\mathrm{Cm} 19$ & Corrientes & 2013 & II & - & + & + & + & + & + & + & + & V. Obregón \\
\hline $\mathrm{Cm} 21$ & Mendoza & 2012 & II & - & + & + & + & + & + & + & + & This study \\
\hline $\mathrm{Cm} 22$ & Mendoza & 2012 & II & - & + & + & + & + & + & + & + & This study \\
\hline $\mathrm{Cm} 23$ & Mendoza & 2012 & II & - & + & + & + & + & + & + & + & This study \\
\hline $\mathrm{Cm} 24$ & Mendoza & 2012 & II & - & + & + & + & + & + & + & + & This study \\
\hline $\mathrm{Cm} 25$ & Buenos Aires & 2011 & II & - & + & + & + & + & + & + & + & This study \\
\hline $\mathrm{Cm} 27$ & Buenos Aires & 2011 & II & - & + & + & + & + & + & + & + & Wassermann et al., 2017 \\
\hline $\mathrm{Cm} 29$ & Buenos Aires & 2011 & II & - & + & + & + & + & + & + & + & This study \\
\hline $\mathrm{Cm} 30^{* *}$ & Buenos Aires & 2011 & II & - & + & + & + & + & + & + & + & This study \\
\hline $\mathrm{Cm} 31$ & Corrientes & 2012 & II & - & + & + & + & + & + & + & + & V. Obregón \\
\hline $\mathrm{Cm} 32$ & Corrientes & 2011 & II & - & + & + & + & + & + & + & + & V. Obregón \\
\hline $\mathrm{Cm} 34$ & Buenos Aires & 2011 & II & - & + & + & + & + & + & + & + & Wassermann et al., 2017 \\
\hline
\end{tabular}




\begin{tabular}{|c|c|c|c|c|c|c|c|c|c|c|c|c|}
\hline $\mathrm{Cm} 36$ & Buenos Aires & 2012 & II & - & + & + & + & + & + & + & + & This study \\
\hline $\mathrm{Cm} 37$ & Buenos Aires & 2013 & II & - & + & + & + & + & + & + & + & This study \\
\hline $\mathrm{Cm} 38$ & Buenos Aires & 2013 & II & - & + & + & + & + & + & + & + & Wassermann et al., 2017 \\
\hline Cm39 & Buenos Aires & 2013 & II & - & + & + & + & + & + & + & + & This study \\
\hline $\mathrm{Cm} 42$ & Buenos Aires & 2010 & II & - & + & + & + & + & + & + & + & This study \\
\hline $\mathrm{Cm} 46$ & Buenos Aires & 2010 & II & - & + & + & + & + & + & + & + & This study \\
\hline Cm58 & Buenos Aires & 2009 & II & - & + & + & + & + & + & + & + & Wassermann et al., 2017 \\
\hline Cm59 & Buenos Aires & 2009 & II & - & + & + & + & + & + & + & + & This study \\
\hline $\mathrm{Cm} 90^{* *}$ & Buenos Aires & 2011 & II & - & + & + & + & + & + & + & + & This study \\
\hline Cm91 & Buenos Aires & 2011 & II & - & + & + & + & + & + & + & + & This study \\
\hline $\mathrm{Cm} 93$ & Buenos Aires & 2011 & II & - & + & + & + & + & + & + & + & This study \\
\hline $\mathrm{Cm} 95^{*}$ & Buenos Aires & 2011 & II & - & + & + & + & + & + & + & + & This study \\
\hline $\mathrm{Cm} 96$ & Seeds & 2011 & II & - & + & + & + & + & + & + & + & This study \\
\hline $\mathrm{Cm} 124$ & Tucumán & 2013 & II & - & + & + & + & + & + & + & + & C. Flores \\
\hline $\mathrm{Cm} 125$ & Tucumán & 2013 & II & - & + & + & + & + & + & + & + & C. Flores \\
\hline $\mathrm{Cm} 7$ & Buenos Aires & 2000 & III & + & + & + & + & + & + & + & + & Wassermann et al., 2017 \\
\hline $\mathrm{Cm} 16$ & Mendoza & 2013 & III & + & + & + & + & + & + & + & + & This study \\
\hline $\mathrm{Cm} 17$ & Mendoza & 2013 & III & ND & ND & ND & ND & ND & ND & ND & ND & This study \\
\hline $\mathrm{Cm} 43$ & Buenos Aires & 2010 & III & + & + & + & + & + & + & + & + & This study \\
\hline $\mathrm{Cm} 120$ & Tucumán & 2013 & III & ND & ND & ND & ND & ND & ND & ND & ND & C. Flores \\
\hline $\mathrm{Cm} 121$ & Tucumán & 2013 & III & + & + & + & + & + & + & + & + & C. Flores \\
\hline $\mathrm{Cm} 122$ & Tucumán & 2013 & III & + & + & + & + & + & + & + & + & C. Flores \\
\hline NCPPB382 & United Kingdom & 1956 & IV & + & + & + & + & + & + & + & + & NCPPB culture collection \\
\hline
\end{tabular}

${ }^{\text {a }}$ Strains marked with the same number of asterisks were isolated from the same tomato plant.

${ }^{\mathrm{b}}+$ and - indicate the positive or negative detection of the corresponding gene by PCR, respectively. ND: not determined

${ }^{\mathrm{c}} \mathrm{V}$. Obregón and C. Flores from EEA Bella Vista and EEA Yuto, INTA, kindly provided us the strains from Corrientes and Tucumán. 


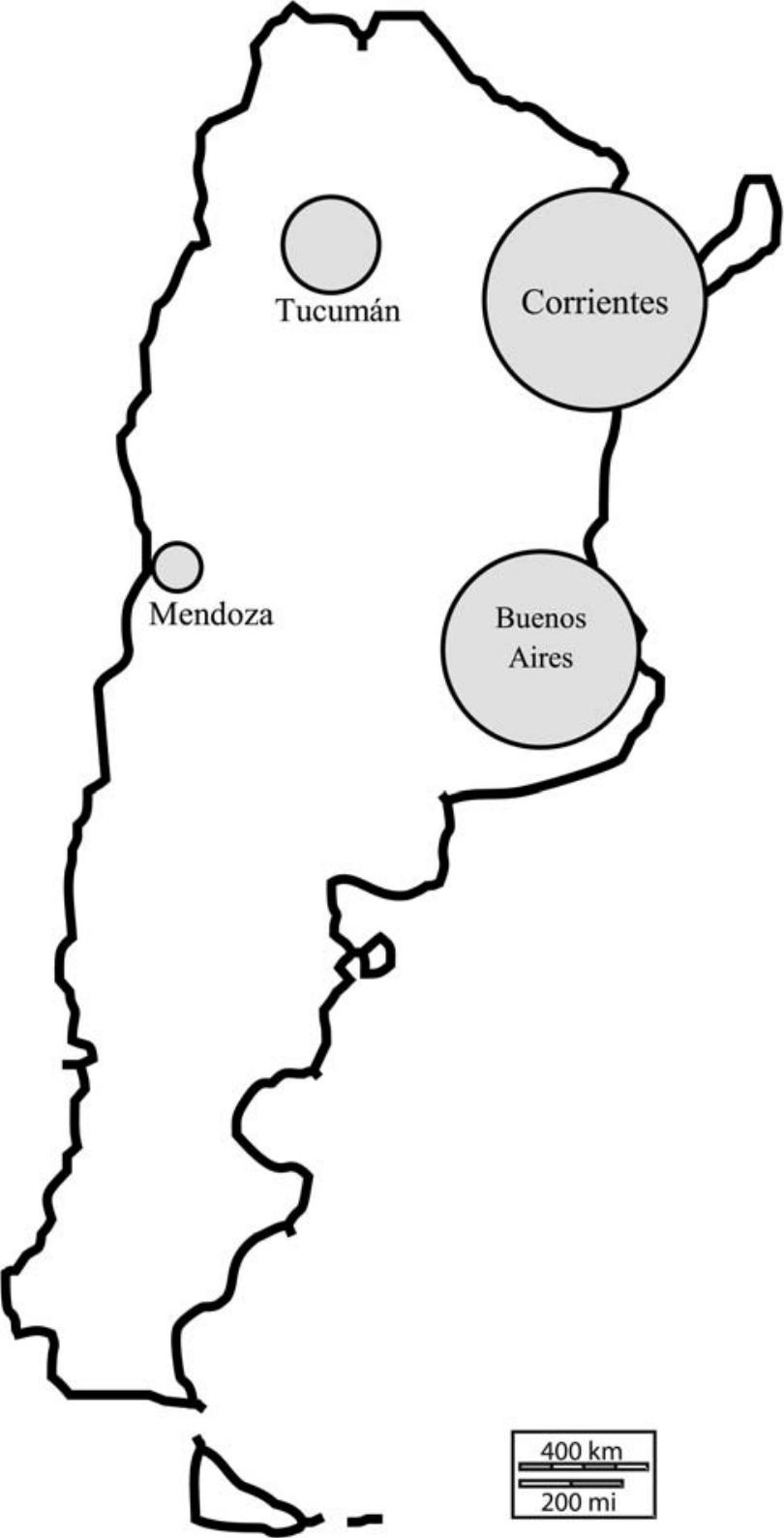


